\title{
Инжиниринговое сопровождение достройки проблемных объектов. Экспертное мнение
}

\author{
Е.Л.Беляева, ИГБИ, Москва \\ Н.В.Хлебникова, ИГБИ, Москва
}

А.В.Маргулец, архитектурная мастерская «Марвин и Ко», Москва

С.Б.Дари, Межрегиональный центр оценки и экспертизы, Москва

Рассмотрены масштабы незавершённого строительства многоквартирных жилых домов, возводившихся по договорам долевого участия с привлечением средств граждан, предпосылки формирования проблемных ситуаций, их градостроительные, социальные и технические аспекты. «Долгострои» были и в СССР. В условиях рыночной экономики, вероятность сбоев в финансировании, материальнотехническом обеспечении, в оформлении разрешительной и технической документации возросла. Несмотря на действующую много лет систему государственной регистрации договоров долевого участия и других мер государственного регулирования долевого строительства (214-ФЗ и др.), на практике достаточно часто возникали сложные социально-градостроительные ситуации, затрагивающие интересы большого количества пострадавших граждан, которые вынуждены много лет ждать достройки многоквартирного дома или выплаты компенсации.

Показано, что последние изменения в законодательстве предполагают индивидуальные подходы к достройке проблемных объектов, использующие инжиниринговое сопровождения. Считается, что это должно обеспечить снижение административных барьеров, сокращение срока завершения работ, оптимизацию затрат и разрешение сложившихся социально-конфликтных ситуаций. Однако, методика выполнения таких работ отсутствует.

Рассмотрены цели, задачи и требования к методике инжинирингового сопровождения достройки проблемного объекта, которая должна стать инструментом обоснования, принятия и реализации решений в рассматриваемой области. Предложено создание специализированной нормативно-методической базы с использованием экспертных методов.

Статья исследует актуальное междисциплинарное направление достройки «проблемных объектов» и не относится к конкретной сфере инвестиционно-строительной деятельности. Рассмотрены факторы, влияющие на формирование проблемных ситуаций и факторы, условия, необходимые для ее решения.

Ключевые слова: проблемные объекты незавершенного строительства, многоквартирные жилые дома, инжиниринговое сопровождение достройки, междисциплинарные исследования, нормативная методика.
Engineering support for completion of "problematic objects". Engineering support tasks (expert opinion)

E.L.Belyaeva, IGBI, Moscow

N.V.Khlebnikova, IGBI, Moscow

A.V.Margulets, architectural studio "Marvin and Co", Moscow

S.B.Dari, Interregional Center for Assessment and Expertise, Moscow

The article considers the scale of unfinished construction of apartment houses built with the attraction of funds of citizensparticipants of share construction, preconditions of formation of problematic situations, its town-planning, social and technical aspects. In conditions of market economy and reduction of the role of state regulation in the construction industry the probability of failures in the financing of construction, in material and technical support and preparation of permit and technical documentation increased. Despite the current legal regulation in the field of shared ownership construction (214$\mathrm{FZ}$, etc.) in practice sometimes arise difficult problematic social and urban situations affecting the interests of a large number of "affected citizens" who have to wait for 5, 10, 15 years or more for the completion of construction or to get compensation payments when the completion was impossible.

The article shows that the last legislative changes presuppose individual approaches to the completion of the problematic objects with the use of "engineering support" which should provide administrative barriers lowering, acceleration, and cost optimization for the object completion and the solution of the developed socially-conflict situations. The goals and objectives of "engineering support" are considered as a tool for justification, adoption, and implementation of urban planning and technical solutions in this area.

It is proposed to create a specialized regulatory and methodological framework of "engineering support" for completion of problematic objects.

The article is a survey that characterizes an actual interdisciplinary problem and does not refer to any particular sphere of construction activity, for example, investmentfinancial, town-planning or technology of construction production, but includes all these directions, orienting them to an understanding of the significance of social result overcoming of quite recurrent problematic situations within the existing legal field by methods of engineering support. 
Keywords: problematic objects, shared construction of apartment blocks, engineering support of completion, interdisciplinary research, normative methodology.

\section{Условия и предпосылки возникновения проблемных ситуаций}

В последние годы вопросам незавершённого строительства в жилищной сфере уделяется повышенное внимание. Совершенствуется федеральное и региональное законодательство ${ }^{1}$. В субъектах Федерации в данном направлении работают Министерства жилищной политики, банки, «Фонды содействия пострадавшим гражданам». Проблемой активно занимаются администрации регионов и городов, однако заметных результатов в уменьшении количества долгостроев нет.

Проблема обманутых дольщиков в условиях рыночной экономики формировалась постепенно, в течении 10-15 лет при действующем законе «0б участии граждан в долевом строительстве» (№214-Ф3). Особенно она обострилась в последние пять лет в результате следовавших друг за другом экономических кризисов $(2014,2018-2021)$ и массового банкротства застройщиков.

При очень большом количестве проблемных объектов и пострадавших граждан у государства не было реальной возможности организовать достройку незавершённых объектов или выплату компенсаций. Улучшить ситуацию сложившихся долгостроев дополнения по страхованию договоров долевого участия внесённые в законодательство в 2014 году не могли - они не касались объектов прежних лет. Региональные фонды, обеспечивающие защиту прав граждан - участников долевого строительства, стали формироваться только со второй половины 2019 года, когда были внесены поправки в 214-Ф3 (151-Ф3). В условиях кризиса в экономике «Фонды...» плохо «наполняются».

Как следует относиться долевому строительству и его результатам? Когда проблемных ситуаций стало много в Москве, Московской области и других городах, некоторые стали говорить, что инвестирование было дело добровольное и рассчитывать нужно на себя.

Участие в долевом строительстве многоквартирных домов - это не «МММ», а экономически оправданный способ привлечения денежных средств населения в строительство жилья, который просуществовал много лет и во многом дал положительные результаты. По масштабу и реальному значению можно считать, что это уникальный метод инвестирования в строительство многоквартирных жилых домов для среднего класса, соответствующий социальным возможностям и интересам российского общества на определённом этапе его развития.

За рубежом в области строительства недорогого жилья в основном используются известные американские подходы «Фаннимэй» («Fanniemai») и его последующие трансформации. На их пути тоже бывали кризисы, которые преодолевались с помощью государства, да и сегодня без его помощи никто не обходится. В нашей стране значительная часть населения, участвующего в долевом строительстве, использует различные виды государственной поддержки (ограничения процента по ипотечным кредитам, материнский капитал, военная ипотека), то есть пока население доверяет гарантиям государства, долевое строительство сможет обеспечить значительный социальный эффект. Это требует совершенствования законодательства и других мер государственного регулирования, но главное - требует исполнения ранее данных государством обязательств по достройке проблемных объектов или возмещению средств пострадавшим гражданам из средств специальных фондов (151-Ф3).

Благодаря масштабному строительству многоквартирных жилых домов с привлечением средств граждан в России за последние 10-15 лет удалось существенно повысить жилищную обеспеченность в регионах и городах: в среднем с 15-20 до 30-40 кв. м на человека, улучшить жилищные условия и комфортность жилья значительной части населения, повысить демографическую манёвренность жилого фонда за счёт достигнутого разнообразия квартир, видов и категорий жилья. Была обеспечена возможность выбора жилья, различающегося по условиям размещения, по стоимости, категориям комфортности, исходя из социальных предпочтений и финансовых возможностей участников долевого строительства.

Таким образом, в рыночных условиях через специфические рыночные инструменты удалось оптимизировать инвестиционные требования к жилью, сложившиеся в различных регионах и городах ${ }^{2}$. Сегодня они учитывают демографический и социальный состав населения, половозрастные особенности, семейный состав, различные требования к благоустройству придомовых территорий при общем повышении экологичности и доступности городской среды для маломобильных групп населения. При долевом строительстве многоквартирных жилых домов в соответствии с современными нормативами, как правило, обеспечивается размещение автостоянок и гаражей из расчёта не менее одного машиноместа на квартиру.

\footnotetext{
${ }^{1}$ Градостроительный кодекс Российской Федерации от 29.12.2004 N 190-Ф3 (ред. от 27.12.2019) (http://www.consultant.ru/document/cons_doc_ LAW_51040/); Федеральный закон от 30.12.2004 № 214-Ф3 «0б участии в долевом строительстве многоквартирных домов и иных объектов недвижимости и о внесении изменений в некоторые законодательные акты Российской Федерации» от 30.12.2004 № 214-Ф3 (http://www.consultant.ru/document/ cons_doc_LAW_51038/); Федеральный закон от 27 июня 2019 г. N 151-Ф3 «0 внесении изменений в Федеральный закон "0б участии в долевом строительстве многоквартирных домов и иных объектов недвижимости и о внесении изменений в некоторые законодательные акты Российской Федерации" и отдельные законодательные акты Российской Федерации» (http://www.consultant.ru/document/cons_doc_LAW_327710/); Федеральный закон от 26.10.2002 № 127-Ф3 «0 несостоятельности (банкротстве)» (последняя редакция) (http://www.consultant.ru/document/cons_doc_LAW_39331/).

${ }^{2}$ Реестр пострадавших граждан (https://gusn.mosreg.ru/hranenie/priznanie-grazhdan-postradavshimi-i-vedenie-i).
} 
Реализованные проекты долевого строительства сделали градостроительными стандартами квартальную планировку и «дворы без машин», индивидуальные архитектурные решения. Сегодня мы имеем большое разнообразие типов жилых домов и технико-экономических показателей застройки участков по площади и этажности - от высотных градостроительных комплексов до малоэтажной блокированной застройки (таунхаусов). Применяются энергоэффективные решения, современное инженерное оборудование. Строительство ведётся комплексно, причем - не только в столице и крупных городах, но и в небольших городских и сельских поселениях.

При значительных объёмах строительства в проекты включают школы, детские сады, поликлиники, объекты торговли и бытового обслуживания. Социальные результаты долевого строительства могут быть шире и распространяться на прилегающие территории. Строительство современной инженерной инфраструктуры, улиц и дорог, дополнительное благоустройство и озеленение способствуют регенерации градостроительного окружения, тем самым учитываются интересы развития территорий и местного населения.

В связи с масштабными инвестиционными проектами долевого строительства проводятся мероприятия по прокладке (реконструкции) магистралей, городских дорог, строительству крупных транспортных развязок и узлов, по прокладке мощных городских и районных коммуникаций. Строятся крупные инженерные сооружения - районные котельные, ТЭЦ, водозаборные узлы, очистные сооружения хозяйственно-бытовой канализации и поверхностного стока, электроподстанции, трансформаторные и газораспределительные станции.

Иногда помощь в решении вопросов строительства социальной и инженерной инфраструктуры оказывают субъекты Федерации или муниципалитеты, но, как правило, эти требования входят в «особые условия размещения» по Инвестконтракту с Застройщиком и в ГПЗУ. В исторических зонах городов в проекты долевого строительства при необходимости включаются мероприятия по обеспечению сохранности памятников архитектуры и ценной градостроительной среды в окружении объекта, по строительному и гидрогеологическому мониторингу.

Все перечисленные факторы, требования и условия не могут не влиять на общую стоимость строительства и сроки сдачи в эксплуатацию. Полностью учесть их на предпроектной стадии и в проекте, как правило, невозможно. Сложность учёта градостроительных факторов размещения - одна из причин появления долгостроев и тысяч обманутых дольщиков.

Для того чтобы построить и сдать в эксплуатацию жилой дом, нужно обеспечить его нормативным благоустройством и озеленением, нормативным инженерным оборудованием и социальной инфраструктурой.

Сложность строительства возрастает в условиях высокоплотной застройки в связи с необходимостью соблюдения нормативов инсоляции и освещённости в размещаемых домах и в окружающей застройке, требований нормативных противопожарных проездов, гостевых автостоянок. Когда «дольщики» видят коробку построенного дома и радуются, что инвесторы их «не обманули», до реального завершения и ввода в эксплуатацию может быть очень далеко.

Таким образом, «Закон об участии граждан в долевом строительстве» (214-Ф3, 151-Ф3) и связанные с ним законы и нормативные акты с нашей точки зрения представляют собой социально значимый инструмент инвестирования в строительство жилья, который необходимо сохранять и совершенствовать. Они должны учитывать вызовы экономических кризисов, которые, к сожалению, «зачастили», несовершенство механизмов инвестирования и недостаточный (в некоторых субъектах) государственный контроль при долевом строительстве многоквартирных домов.

В формировании проблемных долгостроев часто присутствует вина застройщика, не рассчитавшего средства и сроки, необходимые для реализации запланированного строительства. Постепенно на рынке вымывались мелкие застройщики, в Москве, например, сохранились лишь несколько крупнейших компаний.

Известно, что реальное мошенничество и умышленный обман со стороны застройщиков в долевом строительством многоквартирных домов встречается нечасто, что подтверждается рассмотрением судами уголовных дел. В последние годы на формирование проблемных ситуаций значительно влияет другой «человеческий фактор» - когда у участников долевого строительства не хватает терпения дождаться его окончания, а застройщик сталкивается с несогласием своих «партнёров» на несущественный перенос сроков или на небольшие дополнительные инвестиции, необходимые для завершения работ. Застройщика объявляют «мошенником» и подают в уголовный суд. Мошенник застройщик или нет, суд решит, но при большом количестве участников (500 человек и более) такие процессы занимают многие годы, а стройка стоит.

Иногда негативную роль играют органы власти и управления субъекта Федерации, муниципальных образований, которые не могут вовремя урегулировать наметившийся конфликт между застройщиком и участниками долевого строительства, оказать организационную помощь, пока решение проблемы не зашло в тупик.

Причиной недостаточной эффективности деятельности административных органов были административные реформы последнего времени, изменившие сферу ответственности в области долевого строительства. Ещё недавно контроль за долевым строительством полностью осуществлялся на местном уровне. На уровень «субъекта Федерации» он перешёл только в 2014 году. Особенно болезненными были изменения сферы ответственности по объектам долевого строительства в Московской области, в состав которой входило множество муниципалитетов. Здесь до 2014 года ГПЗУ, разрешения на строительство и на ввод в эксплуатацию многоквартирных жилых домов давали местные администрации. 
Долевое жилищное строительство в Московской области не входило в сферу контроля инвестиций. На уровень «Субъекта» эта деятельность перешла только в 2015 году. Во второй половине 2019 года в Московской области было создано «Министерство жилищной политики», важным направлением деятельности которого сегодня является контроль за долевым строительством и достройкой проблемных объектов. Предусмотренный законодательством «Фонд» (изменения в 214-Ф3 и 151-Ф3, 2019 год) был образован только летом 2020 года.

Многолетние проблемные ситуации в долевом строительстве часто связаны с недостаточно эффективной и медленной работой арбитражных судов в делах по банкротству застройщиков, других судебных органов по подтверждению прав пострадавших граждан. Сказывается ангажированность адвокатуры, которая навязывает «инициативным группам» дольщиков агрессивную политику в отношении застройщиков и администрации, необоснованно затягивая процессы, процедуры перехода к конкурсному управлению, при которых становится возможной достройка проблемного объекта.

Можно было ожидать, что с конца 2019 года после изменений в законодательстве (151-Ф3), организации «Фонда», регламентации процедур конкурсного управления по срокам ситуация изменится. Но нет. Снижают возможности административного регулирования и решения вопросов достройки незавершённого строительства уголовные суды, инициированные участниками долевого строительства в отношении застройщиков и «обеспечительные меры» с арестами земли.

В гражданских судах эффективные арбитражные управляющие, имеющие опыт работы с застройщикамибанкротами, знающие градостроительное законодательство и практику - редкость. Подавляющее большинство арбитражных управляющих не считает своим долгом заниматься «достройкой» проблемных объектов и ограничивает свою деятельность юридическими вопросами регистрации и ведения реестра кредиторов, соблюдения прав сторон арбитражного производства в соответствии с законодательством о банкротстве застройщиков ${ }^{3}$.

До принятия Федерального закона № 151-Ф3 обеспечение достройки проблемного объекта не считалось прямой обязанностью внешнего или конкурсного Управляющего. В последние годы опыт работ и знание нормативных документов являются обязательными требованиями к утверждению судом кандидатуры арбитражного Управляющего. Ранее специальной подготовки и аттестации для работы с объектами долевого строительства по линии Арбитражного суда или СРО арбитражные управляющие не проходили. Многие не только не знают градостроительных и технических вопросов достройки проблемных объектов и Градостроительного кодекса, но даже Федерального закона об участии граждан в долевом строитель- стве (№ 214-Ф3), не знакомы с положительным опытом своих коллег, которые благополучно завершили достройку.

Таким образом, «виновных» в многолетних проблемных ситуациях много, но в тоже время - нет никого. Нет ответственных за срыв первоначальных сроков строительства объекта, за уход застройщика и технического заказчика с площадки без консервации объектов, за отсутствие мониторинга долгостроя, нет ответственных за разрушение конструкций и материалов в процессе многолетнего ожидания завершения строительства. Фактически нет ответственных за несоблюдение в этот период на площадке противопожарных, санитарных и экологических требований, что часто сопровождается чрезвычайными ситуациями.

Сегодня вопросы достройки проблемных объектов или выплаты возмещения пострадавшим гражданам, предоставления «натуральных компенсаций» решает «Фонд содействия пострадавшим гражданам - участникам долевого строительства». Курирует федеральную политику в данной области Минстрой России, который действует в рамках Градостроительного кодекса с учётом его изменений по 151-Ф3. Недостаточное знание конкретных проблемных ситуаций, невозможность опереться на поддержку участников долевого строительства, отсутствие нормативно-методических документов, регламентирующих процессы достройки проблемных объектов, - всё это осложняет решение проблем на практике. Приходится принять как факт, что сегодня взаимодействие различных министерств и ведомств, финансовые ресурсы для достройки существенно ограничены.

В сложившихся проблемных ситуациях, как правило, больше страдают не активисты (члены инициативных групп), а законопослушные участники долевого строительства, полностью оплатившие многомиллионные договора участия в долевом строительстве, оформившие ипотечные кредиты и терпеливо ожидающие его окончания. Реестр «пострадавших граждан» ранее вёлся региональными органами Госстройнадзора субъектов Федерации, его ведение отменено. В наиболее сложной ситуации - в Московской области, пострадавших граждан видимо сотни тысяч. Через пять-десять лет у «ипотечников» банки за долги забирают «права-требования» по договорам долевого участия (ДДУ), некоторые «участники» заболевают, некоторые умирают. В последние годы Роспотребнадзор не осуществляет контроль за долевым строительством.

Согласно данным Федерального реестра «проблемных» объектов ${ }^{4}$ на март 2020 года всего в России их насчитывалось 3097, из них в Москве - 177, в Московской области - 749. Сложившаяся ситуация в непосредственном окружении столицы объясняется не только тем, что полномочия по контролю за ведением жилищного строительства здесь осуществлялись на местном уровне, но и тем, что «инвестиционный контроль» за объектами долевого строительства, в отличие, например,

3 Положение о Министерстве жилищной политики Московской области (с изменениями на 27 ceнтября 2019 года) (http://www.consultant.ru/cons/cgi/ online.cgi?req=doc\&base $=$ MOB\&n=300448\#047867452851070125).

${ }^{4}$ Там же. 
от Москвы, не был предусмотрен законодательством «субъекта» ${ }^{5}$. Масштабы долевого строительства в Московской области были очень большими. Известно, что большинство подмосковных объектов долевого строительства требовало значительных вложений в инфраструктуру.

Примером реальных сложностей, с которым сталкиваются инвесторы жилищного строительства, может быть жилой комплекс Фонда РЖС, который разместился на месте выведенной воинской части «Радиострой» - у въезда в Зеленоград со стороны Пятницкого шоссе. Территория расположена недалеко от станции Крюково и хорошо обеспечена транспортом и социальной инфраструктурой Зеленограда. Проект был выполнен зеленоградскими архитекторами и представлял собой группу жилых домов с объектами социально-культурного обслуживания, ДДУ, школой. Строился объект около десяти лет со значительными отклонениями от проекта и до сих пор полностью ещё не реализован.

Казалось, что условия размещения в данном случае достаточно благоприятные: примыкание к городской магистрали, близко ТЭЦ и ЛЭП. В границах участка возрастные лесные насаждения, предполагалось их сохранение и снижение затрат на озеленение.

Однако при реализации возникли трудности: для подключения к городским сетям потребовалось строительство понижающих подстанций, что стало достаточно сложной проблемой. Из-за экономических кризисов не было возможности в достаточном объёме привлечь инвестиции. В результате оказалось, что заявленные сроки строительства не были правильно спрогнозированы. Да и можно ли было объявлять «реальные» сроки строительства объекта - кто вложит деньги в заведомо многолетний проект, грозящий проблемной ситуацией.

Известно, что фактическое количество незавершённых объектов значительно больше, чем зарегистрированных, возможно - в разы. Со второй половины 2019 года процесс государственной регистрации объектов незавершённого строительства, в том числе в Московской области, ускорился в соответствии с требованиями законодательства ${ }^{6}$, однако пока он не завершён. Очевидно, что в 2020 году количество незавершённых объектов увеличилось в связи с пандемией, банкротствами застройщиков, которые начались ещё в 2019 году и продолжаются до сих пор.

Выполненный анализ показывает наличие общего и особенностей в предпосылках и условиях формирования проблемных ситуаций, этим объясняется их многообразие. Для выхода из таких ситуаций в каждом случае требуется индивидуальный подход, а значит углублённое, научно - проектное и экспертное обоснование, основанное на технических обследованиях и ответственных решениях по перспективам, методам и технологиям достройки.

\footnotetext{
${ }^{5}$ Единый реестр проблемных объектов (https://наш.дом.рф/сервисы/ каталог-новостроек/список-проблемных-объектов).

${ }^{6}$ Там же
}

Актуальность разработки научных основ, методологии и нормативных требований по достройке и вводу в эксплуатацию проблемных объектов

Ранее мы убедились, что в последние годы было много сделано для совершенствования и развития законодательства по долевому строительству многоквартирных жилых домов. Изменения в законодательстве в основном были касались правовых мер защиты интересов участников долевого строительства. Организационно-техническим вопросам достройки - тому, что в Федеральном законе №151-Ф3 называют «инжинирингом», созданию соответствующего нормативно-методического обеспечения достаточного внимания не уделялось.

Очевидно, что возможности и условия достройки проблемных объектов могут быть различными в зависимости от технико-экономических показателей объекта, сроков долгостроя, особенностей градостроительных условий, архитектурных и конструктивных решений, от материалов, инженерного обеспечения и технологий возведения зданий, при различиях инженерного, транспортного и социальнокультурного обслуживания. Разные условия достройки разная экономика.

При многолетних долгостроях на первое место безусловно выходит сохранность строительных конструкций и материалов. Мониторингом состояния недостроенных объектов и их консервацией застройщики занимаются редко, как правило - наиболее ответственные, понимающие, что рано или поздно объект придётся «достраивать». В условиях банкротства застройщиков Госстройнадзор практически не отслеживает изменения технического состояния зданий и сооружений. Сегодня даже на качественном уровне нельзя оценить динамику нарастающего разрушения. Масштаб проблемы долгостроев - тоже.

Исследования и литературные данные по процессам разрушения строительных конструкций и материалов по долгостроям нами не обнаружены. В литературе мы не нашли также специальных методов и методик технических обследований, пригодных для экспресс мониторинга состояния объектов незавершённого строительства и принятия решений по целесообразности их достройки или сноса с возмещением цены. На практике используют обычные методы технического обследования, часто разрушающие строительные конструкции, обнажающие арматуру. Объём и методика обследований бывают не обоснованными.

Следует учитывать, что за десять-пятнадцать лет наряду с физическим разрушением происходит моральное старение зданий. Изменение норм безусловно может осложнять достройку проблемных объектов. Это касается вопросов энергоэффективности зданий, пожарной безопасности, особых требований к зданиям, сооружениям. Поменялись требования к благоустройству - в части обеспечения «безбарьерной» среды для маломобильных групп населения. 
Не имея специальной методологии и методики невозможно планировать сроки преодоления сложившихся ситуаций, нельзя заполнить основные сведения в табличках Государственного реестра проблемных объектов. Законодательством (№ 151-Ф3) предусмотрено ведение субъектами Федерации межотраслевой информационной базы состояния таких объектов, пока оно не налажено. Редко в ней содержится достаточно технической информации о незавершённых объектах долевого строительства, о выполненных объёмах работ. Что уж говорить о степени сохранности долгостроев.

Подобная информация по проблемным объектам должным образом не обобщается и не актуализируется, и особенно - по малоэтажному строительству. Например, в посёлке таунхаусов, каким является ЖК «Белый город», более 500 участников долевого строительства. По количеству квартир это сопоставимо с 22-этажным 4-секционным домом КОПЭ, а по показателям общей площади значительно больше такого дома.

При этажности в три этажа и площади блокированных домов меньше 1500 кв. м этот ЖК, согласно Градостроительному кодексу России, не подпадает под контроль Госстройнадзора. То же по объектам и сетям инженерного обеспечения - электроснабжения, водоснабжения, газоснабжения и канализации, поскольку их головные сооружения имеют малую мощность.

На примере ЖК «Белый город» видно, что «малоэтажка» в силу её конструктивных особенностей и высокой доли ограждающих конструкций в общей конструктивной схеме здания подвержена быстрому разрушению под влиянием осадков и температурных факторов. Без консервации и дополнительной гидроизоляции построенные, но не сданные в эксплуатацию дома через два-три года теряют надлежащий внешний вид, быстро теряются эксплуатационные качества здания: снижается гидроизоляция, теплозащита.

Через пять-шесть лет при отсутствии консервации конструкции зданий могут поражаться грибком. При неблагоприятных условиях быстро коррозирует плохо забетонированная арматура, снижается прочность конструкций, разрушаются перекрытия, основания. Особенно уязвимы кровли и верхние перекрытия, многослойные конструкции фасадов, их отделка, входные группы.

Унылый облик «недостроя», социальные конфликты, пережитые участниками долевого строительства, надолго фиксируют за ним репутацию «плохого» объекта недвижимости и в результате резко снижают его рыночную стоимость. Через пять-шесть лет большинство участников долевого строительства предпочтут достройке денежное возмещение или обмен на квартиру в доме, введённом в эксплуатацию, даже если его расположение и комфортность значительно хуже того, что они приобретали.

Нужно учитывать, что каждый год простоя рассматриваемого вида многоквартирных жилых домов осложняет градостроительные, инженерные, технические, экологические условия территории объекта и прилегающих территорий. При достройке «незавершёнки» это потребует дополнительных вложений.
Однако самая сложная проблема - взаимодействие при достройке с участниками долевого строительства. Необходимо не только чётко выполнять требования законодательства, но и знать позицию участников долевого строительства, интересы которых могут различаться. Потребуется помощь социологов. Однако, полностью ответить на такие сложные вопросы и вызовы сможет только междисциплинарное градостроительное, архитектурно-строительное и техническое, экологическое, социологическое, правовое сопровождение, результаты которого должны быть заложены в систему «инжиниринга» достройки проблемного объекта. Такая система должна формироваться в соответствии со Федеральным законом № 151-Ф3, однако для этого нужна междисциплинарная методика.

По нашему мнению, для того, чтобы запустить систему «инжинирингового сопровождения», необходимо разработать научные основы и методику, учитывающие особенности достройки проблемных объектов, использующую знания специалистов экспертного уровня. К таким работам следует привлекать организации и специалистов, способных оптимизировать сложный процесс достройки, правильно расставляя приоритеты и обеспечивая принятие социально и экологически ориентированных решений.

Комплексно, как многоотраслевой задачей, Минстрой России этим не занимался и готовой нормативно-методической базой не располагает. Возможно, этим планирует заниматься «ДомРФ» или «Фонд», в этом случае также необходим междисциплинарный подход и методика, соединяющая несколько отраслевых направлений. Следует создать законодательную и нормативную базу с «расширениями» в сферу градостроительства, технических решений и технологий строительства, в сферу оценки объектов недвижимости, строительного аудита, контроля за состоянием и ведением реестра проблемных объектов, - деятельностью по формированию инвестиционных ресурсов для достройки проблемных объектов, в том числе за счёт средств «Фонда».

Проблемные объекты могут достраиваться с использованием средств «Фонда» или бюджета субъекта. Некоторые субъекты Федерации при отсутствии бюджетных средств в региональном фонде (Московская область) безуспешно ищут на достройку «негосударственных инвесторов». Это трудно. Трудно предоставить инвестору достаточную компенсацию его затрат, например, в виде его доли в строительстве или в виде земельного участка.

Инвесторам трудно работать в условиях банкротства компаний, с «дольщиками», «инициативными группами», часто выдвигающими противоречивые требования, трудно работать по «чужой» проектной документации, при просроченных технических условиях.

Потенциальные инвесторы, конечно, понимают, что достроить «проблемный объект» намного сложнее, чем построить его заново или выполнить реконструкцию с увеличением ТЭП.

Бывает так, что частично реализованные объекты недостроенного жилого комплекса будут иметь «собственников» 
помещений, а земля может быть арестована по решениям судов и здесь административного ресурса будет недостаточно.

0бъективные сложности достройки проблемного объекта могут вести к срыву сроков, установленных для инвестора «дорожной картой», утверждённой администрацией субъекта, возможно даже к банкротству нового застройщика. Достроить объект незавершённого строительства, пригласив на него нового застройщика, скорее всего не удастся, это лишь продлит агонию долгостроя.

Более целесообразной является достройка проблемных объектов под контролем администрации субъектов Федерации в сотрудничестве с конкурсными управляющим в рамках его полномочий или путём создания ЖСК. Она может осуществляться с учётом требований по инжиниринговому сопровождению в соответствии с Федеральным законом № 151-Ф3. Однако эта деятельность будет результативной только при появлении на рынке компаний, специализирующихся на достройке проблемных объектов, которые будут знать особенности таких работ, законодательство и обязательно обладать опытными специалистами экспертного уровня, владеющими междисциплинарными знаниями, современными технологиями, применяющими новейшие материалы.

В области инжинирингового сопровождения достройки проблемных объектов обязательной является высокая квалификация организаций. Целесообразно ввести лицензирование по линии Минстроя России. Необходимо разработать специальные нормативные документы на уровне методических указаний, регламентирующих состав и содержание работ. Этот документ может быть передан специализированной государственной структуре «ДОМ РФ», привлекающей на конкурсной основе лицензированных подрядчиков и способной обеспечить комплексную деятельность и финансирование работ в области решения вопросов незавершённого строительства многоквартирных жилых домов.

Известно, что среди проблемных объектов существует достаточно много практически построенных домов, по разным причинам в своё время не введённых в эксплуатацию. Иногда это составные части жилых комплексов, строящихся по очередям. Для решения общей проблемы достройки проблемных объектов и «улучшения статистики» целесообразно с помощью средств Фонда обследовать их и сдать в эксплуатацию. Для подготовки к сдаче целесообразно использовать методы советского периода - так называемые «народные стройки» - особенно в части благоустройства и обновления фасадов.

При относительно небольшом объёме незавершённых строительно-монтажных работ (до 15-20\% общего объёма) достройка проблемных объектов может осуществляться конкурсным управляющим в рамках его полномочий или путём организации ЖСК. В современных сложныхусловиях финансирования в период пандемии это направление может получить развитие в случае, если оно будет соответствовать требованиям законодательства (№ 214-Ф3 и № 515-Ф3), использовать норма- тивные документы и привлекать лицензированные организации. В этих случаях участие специалистов экспертного уровня и квалифицированное инжиниринговое сопровождение на основе специальной нормативной методики.

\section{Заключение}

Учитывая остроту, сложность, междисциплинарный характер проблемы незавершённого строительства при возведении многоквартирных жилых домов с привлечением средств граждан, необходимы государственные меры по приведению в соответствие с действующим законодательством всей системы финансирования, организации и технического сопровождения их достройки.

Минстрою России необходимо разработать методические указания по достройке проблемных объектов в соответствии с требованиями Федерального закона № 151-Ф3 на основе инжинирингового сопровождения. Для создания такого актуального документа (методики) целесообразно выполнить специальные исследования процессов разрушения строительных конструкций не достроенных зданий основных конструктивных схем, распространённых элементов и материалов, которые составят основу будущих классификаций и критериев принятия решений.

При разработке нормативной методики следует учесть градостроительные, архитектурно-строительные, технические, технологические, инженерные, экологические, санитарные, противопожарные и иные нормы, последние изменения нормативных требований, обеспечивающих безопасность и энергоэффективность объектов строительства.

В составе нормативной методики рекомендуется выполнить разделы по техническому обследованию зданий, сооружений, сетей с использованием методов неразрушающих конструкций, а также разделы инженерно-экологических и гидрогеологических изысканий. Рекомендуется разработать специальную систему мониторинга строительных конструкций при ведении работ, а также санитарно-гигиенических исследований в зданиях, сооружениях и на территории.

\section{Лuтература}

1. Акимкин, Е.М. Конфликтные социально-градостроительные ситуации вокруг незавершённого строительства [Электронный ресурс] / Е.М. Акимкин, Е.Л. Беляева, Н.В. Хлебникова // Социология и общество: традиции и инновации в социальном развитии регионов : Сборник докладов VI Всероссийского социологического конгресса. Тюмень, 14-16 октября 2020 г.) / В. А. Мансуров (отв.ред.). - М. : РОС; ФНИСЦ РАН, 2020 6003 с. - Режим доступа: https://www.ssa-rss.ru/VSK-VI\%20 Sbornik/Section\%2019.html (дата обращения 18.01.2021). ISBN 978-5-904804-30-5. DOI:10.19181/kongress.2020

2. Оценка состояния и изменений городской среды России в 2020 г. [Электронный ресурс] // Дом РФ. Официальный сайт. - Режим доступа: https://files.gorodsreda.ru/ upload/70oprosDom.pdf (дата обращения 10.01.2021). 
3. Стандарт комплексного развития территорий [Электронный ресурс] / КБ Стрелка // Дом РФ. Официальный сайт. Режим доступа: https://дом.рф/urban/standards/printsipykompleksnogo-razvitiya-territoriy/\#book2 (дата обращения 06.01.2021)

4. Генгут, И.Б. Экономические механизмы управления ликвидацией накопленного экологического ущерба [Электронный ресурс] // Современные проблемы управления инвестиционно-строительной сфере и природопользовании : Сборник докладов X Международной научно-практической конференции, посвящённой 113-летию РЭУ им. Г.В. Плеханова. 8-12 апреля 2020 года / под ред. В.И. Ресина. - М. : РЭУ им. Г. В. Плеханова, 2020. - 400 с. - Режим доступа: http:// ords.rea.ru/wp-content/uploads/2017/02/Gengut.pdf. (дата обращения 18.01.2021). ISBN 978-5-7307-1653-7

5. Градостроительство : Справочник проектировщика / В.Н. Белоусов [и др.]. - М. : Стройиздат, 1978. - 367 с.

6. Справочник проектировщика промышленных, жилых и общественных зданий и сооружений. Расчётно-теоретический / Уманский А.А. (ред.). - М. : Стройиздат, 1960. - 1041 с.

7. Справочник по теплоснабжению и вентиляции. Часть 1. Отопление и теплоснабжение / Р.В. Щекин [и др.]. Издание четвертое, переработанное и дополненное. - Киев, Будівельник 1976. - 416 c.

8. Справочник проектировщика. Внутренние санитарнотехнические устройства. Часть 2. Водопровод, канализация, газоснабжение / под общ.ред. И.Г. Староверова, Ю.И. Шиллера. - М. : Стройиздат, 1990. - 344 С.

9. Кузнецов Д. Справочник заказчика технического обследования, экспертизы здания. Строительная экспертиза. Июль 2007 г. [Электронный ресурс] // Сайт «Независимая строительная экспертиза, судебно-строительная экспертиза». - Режим доступа: http://e-p-s.ru/spr/text_s.php?text=cena\&pn=0 (дата обращения: 28.12.2020).

10. Симанович, B.М. Справочное пособие для заказчика строительства. Том 1. Инвестиционная деятельность в строительстве и её участники / В.М. Симанович, Е.Е. Ермолаев, Т.Л. Грищенкова - М. : Стройинформиздат, 2013. - 125 с.

11. Кабакова, С.И. Градостроительная оценка территорий городов / С. И. Кабакова. - М. : Стройиздат, 1973. - 150 с.

\section{Refrences}

1. Akimkin E.M Belyaeva E.L., Khlebnikova N.V. Konfliktnye sotsial'no-gradostroitel'nye situatsii vokrug nezavershennogo stroitel'stva [Conflict social and urban planning situations around unfinished construction]. In: Sotsiologiya i obshchestvo: traditsii $i$ innovatsii $v$ sotsial'nom razvitii regionov : Sbornik dokladov VI Vserossiiskogo sotsiologicheskogo kongressa [Sociology and Society: Traditions and Innovations in the Social Development of Regions: Collection of Reports of the VI All-Russian Sociological Congress]. Tyumen, 0ctober 14-16, 2020, A. Mansurov (ed.). Moscow, ROS; FNISTs RAN Publ., 2020, 6003 p. Access mode: https://www.ssa-rss.ru/VSK-VI\%20
Sbornik/Section\%2019.html (Accessed 01/18/2021). ISBN 978-5-904804-30-5. D0I:10.19181/kongress.2020 (In Russ.)

2. Otsenka sostoyaniya i izmenenii gorodskoi sredy Rossii v $2020 \mathrm{~g}$. [Assessment of the state and changes in the urban environment of Russia in 2020]. Dom RF, official site. Access mode: https://files.gorodsreda.ru/upload/70oprosDom.pdf (Accessed 01/10/2020). (In Russ.)

3. Standart kompleksnogo razvitiya territorii [Standard for the integrated development of territories], KB Strelka. Dom RF. Official site. Access mode: https://dom.rf/urban/standards/ printsipy-kompleksnogo-razvitiya-territoriy/\#book2 (Accessed 01/06/2021). (In Russ.)

4. Gengut I.B. Ekonomicheskie mekhanizmy upravleniya likvidatsiei nakoplennogo ekologicheskogo ushcherba [Economic mechanisms for managing the elimination of accumulated environmental damage]. In: V.I. Resin (ed.) Sovremennye problemy upravleniya investitsionno-stroitel'noi sfere i prirodopol'zovanii : Sbornik dokladov X Mezhdunarodnoi nauchno-prakticheskoi konferentsii, posvyashchennoi 113-letiyu REU im. G.V. Plekhanova, [Modern problems of management of the investment and construction sector and environmental management: Collection of reports of the XInternational scientif ic-practical conference dedicated to the 113th anniversary of the REU named after G.V. Plekhanov] April 8-12, 2020. Moscow, REU im. G.V. Plekhanova Publ., 2020, 400 p. Access mode: http://or ds.rea.ru/wp-content/ uploads/2017/02/Gengut.pdf (Accessed 01/18/2021). ISBN 978-5-7307-1653-7 (In Russ.)

5. Belousov V.N. (ed.) Gradostroitel'stvo : Spravochnik proektirovshchika [Urban planning. Designer handbook]. Moscow, Stroiizdat Publ., 1978, 367 p. (In Russ.)

6. Umanskii A.A. (ed.) Spravochnik proektirovshchika promyshlennykh, zhilykh i obshchestvennykh zdanii i sooruzhenii. Raschetno-teoreticheskii [Directory of the designer of industrial, residential and public buildings and structures. Calculationtheoretical]. Moscow, Stroiizdat Publ., 1960, 1041 p. (In Russ.)

7. Shchekin R.V. [et al.]. Spravochnik po teplosnabzheniyu i ventilyatsii. Chast'1. Otoplenie i teplosnabzhenie [Handbook of heat supply and ventilation. Part 1. Heating and heat supply]. Kiev, Budivel'nik Publ., 1976, 416 p. (In Russ.)

8. Staroverov I.G., Shiller Yu.I. (eds.) Spravochnik proektirovshchika. Vnutrennie sanitarno-tekhnicheskie ustroistva. Chast' 2. Vodoprovod, kanalizatsiya, gazosnabzhenie [Designer handbook. Internal sanitary facilities. Part 2. Water supply, sewerage, gas supply]. Moscow, Stroiizdat Publ., 1990, 344 p. (In Russ.)

9. Kuznetsov D. Spravochnik zakazchika tekhnicheskogo obsledovaniya, ekspertizy zdaniya, Stroitel'naya ekspert iza, iyul' $2007 \mathrm{~g}$. [Customer reference book for technical inspection, building expertise. Construction expertise. July 2007]. Sait Nezavisimaya stroitel'naya ekspertiza, sudebno-stroitel'naya ekspertiza [Independent construction expertise, forensic construction expertise]. Access mode: http://e-p-s.ru/spr/ text_s.php?text=cena\&pn=0 (Accessed 12/28/2020). (In Russ.) 
11. Simanovich V.M. Ermolaev E.E., Grishchenkov T.L. Spravochnoe posobie dlya zakazchika stroitel'stva. Tom 1. Investitsionnaya deyatel'nost' v stroitel'stve i ee uchastniki [Handbook for the construct ion customer. Volume 1. Investment activity in construction and its participants]. Moscow, Stroiinformizdat Publ., 2013, 125 p. (In Russ.)

12. Kabakova S.I. Gradostroitel'naya otsenka territorii gorodov [Urban planning assessment of urban areas]. M., Stroiizdat Publ., 1973, 150 p. (In Russ.)

Перечень нормативно-правовых актов и источников

13. ПП МО от 03.0.2015 № 754/24 «0 порядке заключения, изменения и расторжения соглашений о реализации инвестиционных проектов на территории Московской области». Раздел 1, в т.ч. п.5 // Нормативно-правовой портал «КонсультантПлюс». - Режим доступа : http://www.consultant.ru/cons/cgi/ online.cgi? $r e q=$ doc $\&$ base $=$ MOB $\& n=276537 \# 08100774390380212$ (дата обращения 16.01.2021).

14. Резолюция Общероссийского съезда дольщиков, пайщиков жилья и апартаментов / Подготовлена рабочей группой участников жилищного строительства 25.04.2017. - Режим доступа: https://kprf.ru/actions/civilresistance/165005.html (дата обращения 26.12.2020).

15. Постановление Правительства Московской области от 21 февраля 2017 г. № 124/7 «0 внесении изменений в По- становление Правительства Московской области от 17.08.2015 № 713/30 "0б утверждении нормативов градостроительного проектирования Московской области"» // Нормативно-правовой портал «КонсультантПлюс». - Режим доступа: http:// www.consultant.ru/cons/cgi/online.cgi? $r e q=d o c \& b a s e=M O B$ $\& n=247117 \# 05518176729296687$ (дата обращения 13.01.2021).

16. Постановление Правительства Московской области от 09.10.2017 г. № 835/30 «0б утверждении методики определения устойчивости развития территории, в границах которой предусматривается осуществление деятельности по комплексному и устойчивому развитию территории» // Нормативно-правовой портал «КонсультантПлюс». - Режим доступа: http:// www.consultant.ru/cons/cgi/online.cgi?re $q=$ doc\&base $=$ MOB $\& n=308328 \# 08413835098348021$ (дата обращения 22.12.2020).

17. Постановление Правительства РФ от 16.02.2008 № 87 (ред. от 06.07.2019) «0 составе разделов проектной документации и требованиях к их содержанию» // Нормативно-правовой портал «КонсультантПлюс». - Режим доступа: http://www.consultant.ru/ document/cons_doc_LAW_75048/(дата обращения 22.12.2020).

18. Энергоэффективность жилых и общественных зданий нормативы по теплозащите зданий : ТСН 23-322-2001 Костромской области, 2001. [Электронный ресурс] // Библиотека нормативной документации. Режим доступа: https://files. stroyinf.ru/ Data2/1/4294848/4294848161.htm (дата обращения 16.12.2020).

Беляева Елена Львовна (Москва). Кандидат технических наук, советник РААСН, член-корреспондент РАЕН. Директор 000 «Институт геобиосферных исследований» (113105, Москва, Варшавское шосcе, 8. 000 «ИГБИ»). Эл.почта: igbi@уandex.ru.

Хлебникова Нина Владимировна (Москва). Ведущий инженер 000 «Институт геобиосферных исследований» (113105, Москва, Варшавское шоссе, 8. 000 «ИГБИ»).

Маргулец Александр Владимирович (Москва). Генеральный директор 000 «Архитектурная мастерская "Марвин и Ко"» (105122, Москва, Щёлковское ш., 5. АМ «Марвин и Ко»). Эл. почта: mar-win@yandex.ru.

Дари Сергей Борисович (Москва). Генеральный Директор 000 «Межрегиональный центр оценки и экспертизы» (119019, Москва, Новый Арбат, д. 21, оф. 12-35).

Belyaeva Elena L. (Moscow). Candidate of Technical Sciences, Advisor of RAACS, Corresponding Member of the Russian Academy of Natural Sciences. Director of the 000 "Institute of Geobiosphere Research" (8 Varshavskoe shosse, Moscow, 113105. IGBI). E-mail: igbi@yandex.ru.

Khlebnikova Nina V. (Moscow). Leading Engineer at the 000 "Institute of Geobiosphere Research" (8 Varshavskoe shosse, Moscow, 113105. IGBI).

Margulets Alexander V. (Moscow). General Director of 000 "Architectural Workshop "Marvin and Co"" (5 Shchelkovskoe shosse, Moscow, 105122. AM "Marvin and Co"). E-mail: mar-win@yandex.ru.

Dari Sergey B. (Moscow). General Director of the 000 "Interregional Center for Assessment and Expertise" (21 Novy Arbat st., office 12-35, Moscow, 119019). 